\title{
THE INFLUENCE OF IMPLEMENTING NON-FORMAL SUPERVISION ON TEACHER PERFORMANCE IN SUSTAINABLE PROFESSIONAL DEVELOPMENT AT STATE JUNIOR HIGH SCHOOLS OF MAKASSAR
}

\author{
Siti Ariati Jihad ${ }^{1}$ \\ St. Syamsudduha ${ }^{2}$ \\ Muhammad Yahya ${ }^{3}$ \\ Postgraduate Program of UIN Alaudin Makassar ${ }^{1,2,3}$ \\ ariatijihad@gmail.com ${ }^{1}$
}

\begin{abstract}
The aims of this study are to: (1) describe the implementation of nonformal supervision at state Junior High Schools of Makassar (2) describe teacher performance in Continuing Professional Development (CPD) at state Junior High Schools of Makassar (3) describe the effect of implementing non-formal supervision on teacher performance in Continuous Professional Development. This research is quantitative research with the type of ex-post-facto research. The approach used is a sociological, psychological, and quantitative approach. The population in this study was 40 State Junior High schools (SMPN) in Makassar. The samples in this study were SMPN 29 Makassar that included 15 teachers, and SMPN 8 Makassar, with 15 teachers who had been certified using a multistage random sampling technique to assess performance in CPD and principals to determine the implementation of non-formal supervision. The results obtained in this study indicate that: (1) The results of the descriptive analysis of non-formal supervision at SMPN Makassar are in the Very High category with a frequency of 15 people from 30 samples and or 50\%. 2) The results of the descriptive analysis The assessment of teacher performance in Continuous Professional Development is in the Very High category with a frequency of 11 people out of 30 samples or $36.66 \%$. (3) The results of the inferential analysis comparing ttable and $t_{\text {count }}$, it turns out that $t_{\text {count }}=2.137>t_{\text {table }}$ $=2.048$, then $\mathrm{H}_{\mathrm{o}}$ is rejected and $\mathrm{H}_{1}$ is accepted so that it is known that there is a significant effect of non-formal supervision $(\mathrm{X})$ and teacher performance in Continuing Professional Development (Y) at SMPN Makassar. The implications of this research are: (1) the implementation of non-formal supervision at SMPN Makassar, in general, can be applied and maintained. (2) Teacher Performance Assessment in Sustainable Professional Development, in general, can be applied and improved again and can be used as a model for other schools in the application of supervision.
\end{abstract}

Keywords: Non-Formal Supervision, Teacher performance, Continuing Professional Development.

\section{BACKGROUND}

The teacher is the central point in the learning process where the teacher should make students motivated to learn. This is, of course, by providing interesting learning resources according to the needs and differences of students and their suitability with the learning materials. Thus, quality teacher performance is needed to achieve educational goals. 
When supervision is faced with the performance and quality control of education by the supervisor of the education unit, of course, it has a different mission from the supervision by the principal. A supervisor fosters academic quality improvement related to efforts to create better learning conditions in educational aspects, not merely physical material problems. This aims to provide services to school principals in developing the quality of educational institutions and facilitating school principals to carry out institutional management effectively and efficiently.

Supervision management is a separate discipline carried out by supervisors in directing teachers to achieve goals. Management as a process, supervision management includes how to coordinate and integrate various sources to achieve organizational goals (productivity and satisfaction by involving other people). 1

The supervisor's duty in schools is to ensure that all organizational activities can be carried out with a high level of efficiency, effectiveness, and productivity. Therefore, a supervisor providing supervision services, which is a process specifically designed to assist teachers in learning daily tasks at school, is expected to provide services effectively and efficiently to make the school a more effective learning community.

In accordance with its function, the supervisor's role is to provide support, assistance, and shearing. ${ }^{2}$ The supervision carried out is directly related to the professional tasks of teachers, namely: "1) lesson planning skills, 2) teaching implementation skills, and 3) teaching assessment skills". ${ }^{3}$ There are three types of supervision, depending on the item being supervised: 1) academic supervision, 2) administrative supervision, 3 ) institutional supervision. ${ }^{4}$

The following are examples of types of supervision that have been theoretically implemented in the field of education: 1) academic supervision, which is a set of actions aimed at helping teachers improve their capacity to supervise the learning process to meet learning objectives. Academic supervision assists teachers in improving their ability to meet learning objectives. 2) The second type of supervision is non-academic supervision, which involves monitoring and promoting school management and administration. ${ }^{5}$

Non-academic supervision is linked to non-formal supervision. Non-academic supervision is defined as supervisory observations on administrative components that serve as supports and facilitators for learning. Effective and efficient financial management is similar to data management. ${ }^{6}$ This is connected to administrative or nonformal supervision, which is solely to assist and facilitate learning implementation.

Another aspect of non-formal supervision that becomes a focal point is the teacher's position as a servant leader. This term is commonly known as the blusukan supervision model, also known as management by walking around (MBWA), which has been in use since 1973 and encourages leaders to get to know their subordinates, understand their work, and make themselves more visible and accessible. ${ }^{7}$ Non-formal

\footnotetext{
${ }^{1}$ Nanang Fattah, Landasan Manajemen Pendidikan (Cet. V, Bandung: Remaja Rosdakarya, 2000), p. 7.

${ }^{2}$ Piet A. Sahertian, Konsep Dasar dan Teknik Supervisi Pendidikan dalam rangka Pengembangan Sumber Daya Manusia, (PT Rineka Cipta, Jakarta, 2008), p. 25.

${ }^{3}$ Satori, Dj. Supervisi Akademik dan Penjaminan Mutu dalam Pendidikan Persekolahan (Koleksi Materi Perkuliahan Supervisi Pendidikan. Bandung, 2016), p. 5.

${ }^{4}$ Piet A, Sahertian. Konsep Dasar dan Teknik Supervisi Pendidikan, p. 44.

${ }^{5}$ Sahertian Piet, Konsep-Dasar dan Teknik Supervisi Pendidikan Dalam rangka Profesionalisme guru ( Surabaya: Usaha Nasional. 2000), h. 23

${ }^{6}$ Suharsimi Arikunto, Dasar-Dasar Supervisi (Jakarta, Rineka Cipta: 2004), pp. 22-23.

${ }^{7}$ Lee, H., \& Billington, C.The Evolution of Supply Chain Management Models and Practice dalam
} 
supervision in the field of education involves principals as supervisors, mentors, directors, and teachers as servant leaders, namely training, teaching, and educating students. Nonformal supervision, in this case, refers to the other side of a teacher's professional responsibilities as a servant leader in the classroom, where the principal serves as a director and mentor to optimize teacher leadership in the implementation, planning, and as an expert, mediator, and liaison between students. ${ }^{8}$

There are four dimensions of a teacher's role as a servant leader: brokering, participatory leadership, mediation, and relationship forging. ${ }^{9}$ Harris added that through the brokerage, teachers could translate the teachings of school improvement into practice. When operating in a participatory leadership role, teachers feel part of the school's change or development and improvement, and together help fellow teachers by taking on the role of achieving collective goals.

Another key emphasis of non-academic school monitoring by school supervisors is school management. As it is widely known, an issue on school-based management (SBM) has emerged in the previous decade as a type of a new management paradigm. It shifts from centralization to decentralization, giving schools autonomy and increasing community participation. ${ }^{10}$

Regarding the competencies that professional instructors must possess, Article 10 of Law Number 14 of 2005 Concerning Teachers and Lecturers states that teachers must possess four competencies: pedagogic, professional, personality, and social abilities. ${ }^{11}$ These competencies include social competence, personality competence, pedagogical competence, and professional competence. In addition, the efforts made by a teacher in improving his professionalism are in the form of self-development. According to the general guidebook for the Sustainable Professional Development Program, the Directorate General of teachers and education personnel explains that self-development is intended so that teachers are able to achieve or improve their competencies. As mandated in the National Education System Law Number 20 of 2003, a teacher is expected to be able to carry out his main duties and obligations in learning and guiding students, including in terms of carrying out additional tasks that are appropriate and relevant to the school's functions in a professional manner. ${ }^{12}$

The Indonesian government has implemented Continuous Professional Development (CPD) to encourage teachers to enhance their skills on a regular basis. CPD is carried out in response to the needs of teachers to meet professional competency criteria or improve their competence beyond those levels, which has ramifications for gaining credit scores for promotion/teacher functional positions. ${ }^{13}$ In the worldwide community, the term Continuing Professional Development (CPD) is used to characterize teachers'

Hewlett-Packard (Interfaces, 25(5),1995), pp. 42-63.

${ }^{8}$ Harris Abd. Kepemimpinan Pendidikan (Buku Perkuliahan Manajemen Pendidikan Islam. Universitas Islam Negeri Sunan Ampel (UINSA), 2013), h. 80.

${ }^{9}$ Harris Abd. Kepemimpinan Pendidikan. p. 80.

${ }^{10}$ Danim, Sudarwan, Inovasi Pendidikan: Dalam Upaya Peningkatan (Jakarta: Bumi Aksara. 2002), p. 4.

${ }^{11}$ Depdiknas, Undang-Undang Republik Indonesia Nomor 14 Tahun 2005 Tentang Guru dan Dosen (Jakarta: Balai Pustaka, 2008), p. 75

${ }^{12}$ Direktorat Jendral guru dan Tenaga Kependidikan, K. P. N. Melalui Pendidikan dan Pelatihan Guru.( Jakarta, 2018)

${ }^{13}$ Kemendiknas. Pembinaan dan pengembangan profesi guru buku 1: Pedoman pengelolaan pengembangan keprofesian bekelanjutan $(P K B)$. (Direktorat Jenderal Peningkatan Mutu dan Tenaga Kependidikan. 2010). 
attempts to improve their knowledge and skills. Teachers must renew themselves in order to keep up with changing times, which necessitates this CPD endeavor. This aligns with Day's belief that CPD is needed by all teachers to keep up with changes, to examine and refresh their knowledge, abilities, and vision of effective teaching. ${ }^{14}$

Teacher performance indicators, according to the Georgia Department of Education's idea presented in Russman's book, include (1) Lesson Planning, (2) Implementation of Learning Activities (3) Assessment or evaluation of learning. ${ }^{15}$ In this context, initiatives to improve the teaching profession in Indonesia must at the very least address and consider four factors: (a) the availability and quality of prospective teachers, (b) pre-service education, (c) in-service coaching, and (d) the role of professional organizations. ${ }^{16}$

According to the above description, there are inequalities that occur in efforts to achieve educational goals, particularly in relation to improving teacher performance in relation to sustainable professionals, so the authors are interested in conducting research in order to contribute to improving the quality of education in public Junior High Schools in Makassar through non-formal supervision, so the author is interested in conducting research on "The Influence of Implementing Non-Formal Supervision on Teacher Performance in Sustainable Professional Development at State Junior High Schools Of Makassar."

\section{THEORETICAL FRAMEWORK}

\section{A. Non-Formal Supervision Concept}

As described in the first chapter, the term non-formal supervision in this study is basically the adoption of management by walking around (MBWA). Non-formal supervision is a supervision technique that requires personal involvement, good listening skills, and the recognition that most people in an organization want to contribute and are genuinely interested in their position and work (Serrat, 2010). ${ }^{17}$ The non-formal supervision approach has been practiced since 1973, in which leaders are encouraged to know their subordinates, understand the work of their subordinates, and make themselves more visible and accessible. ${ }^{18}$

Rogers stated that MBWA supervisory management consists of tactics where the leader can spend half of the Day walking (monitoring) and talking directly with his subordinates to improve communication and build an objective long-term and short-term attitude. ${ }^{19}$

This supervision, according to Mann, is akin to Toyota's "gemba walks" production approach, in which a leader visits a job site, watches the process, and speaks with employees and subordinates. ${ }^{20}$ The use of non-formal supervision itself requires good listening skills, willingness to participate, belief that every job is important and

\footnotetext{
${ }^{14}$ Day, C. Developing teachers: The challenges of lifelong learning. Taylor \& Francis. 2002.

${ }^{15}$ Rusman, Model-Model Pembelajaran: Mengembangkan Profesionalisme Guru, p. 17.

${ }^{16}$ Usman, Uzer, Menjadi Guru Profesional (Bandung: PT. Remaja Rosdakarya. 2002), pp. 24-25.

${ }^{17}$ Serrat, Olivier. A Primer on Talent Management. Washington, DC: Asian Development Bank, 2010), p. 24.

${ }^{18}$ Lee, H., \& Billington, C. The Evolution of Supply Chain Management Models and Practice dalam Hewlett-Packard. (Interfaces, 25(5), 1995) pp. 42-63.

${ }^{19}$ Rogers, B. Managing Teacher Stress (Financial Times Prentice Hall, London. 1995), p. 145.

${ }^{20}$ Mann, D. The missing link: Lean leadership (Frontiers in Health Services Management 26(1), 2009), p. $15-26$
} 
every employee/subordinate can be trusted and a culture where employees/subordinates feel comfortable in carrying out their work. ${ }^{21}$

Non-formal supervision in the field of education involves principals as supervisors, mentors, directors, and teachers as professional personnel, namely training, teaching, and educating students. In this case, non-formal supervision sees the other side of a teacher's professional duties while in the classroom as a servant leader where the principal's involvement as a director and mentor to optimize teacher leadership in the implementation, planning, an expert, mediator, and liaison between students. ${ }^{22}$

\section{B. Teacher Performance Concept}

Basyaruddin said that teacher performance is designing teaching programs, implementing the learning process, and evaluating assessments. ${ }^{23}$ According to this perspective, teacher performance is determined by the amount of input given to the learning process and the amount of output created in the form of student quality. In another sense, teacher effectiveness is mostly driven by personal abilities as seen by learning outcomes. Ondi Saondi and Ari Suherman claimed that teacher performance reflects success, thus it's critical to assess the workforce's qualities based on three interrelated factors: skills, efforts, and external conditions. ${ }^{24}$

\section{Continuing Professional Development (CPD)}

Continuing Professional Development $(\mathrm{PKB})$ is carried out in accordance with the needs of teachers to achieve professional competency standards or increase their competence above their professional competency standards which at the same time has implications for obtaining credit scores for teacher promotions/teacher functional positions. ${ }^{25}$ In the worldwide community, the term Continuing Professional Development (CPD) is used to characterize teachers' attempts to improve their knowledge and skills. This is in line with Day's opinion that CPD is needed by all teachers to keep pace with changes, to review and update their knowledge, skills, and vision of good teaching. ${ }^{26}$

Collin et al. explained that CPD could be obtained in various forms, from a series of formal education to learning through work practices every day. CPD is targeted to support teachers in gaining the knowledge, skills, and confidence needed to change teacher practices and contribute to better learning. Meanwhile, Bailey stated that through CPD, teachers continuously update their professional knowledge, personal and professional skills, and competencies. ${ }^{27}$

Various forms of self-development activities can be carried out by participating in functional education and training programs as well as participating in teacher collective

${ }^{21}$ Packard, D. The HP Way: How Bill Hewlett and I Built our Company (Harper Business, New York, NY. 1995), p. 79

${ }^{22}$ Harris Abd, Kepemimpinan Pendidikan. Buku Perkuliahan Manajemen Pendidikan Islam. Universitas Islam Negeri Sunan Ampel (UINSA), 2013.), p. 80.

${ }^{23}$ Muh. Basyaruddin Usman, Guru Profesional dan Implimentasi Kurikulum (Cet.1. Jakarta: Ciputat, 2006), p. 9.

${ }^{24}$ Ondi Saondi \& Ari Suherman, Etika Profesi Keguruan, p. 21.

${ }^{25}$ Kemendiknas. Pembinaan dan pengembangan profesi guru buku 1: Pedoman pengelolaan pengembangan keprofesian bekelanjutan $(P K B)$. (Direktorat Jenderal Peningkatan Mutu dan Tenaga Kependidikan. 2010).

${ }^{26}$ Day, C. Developing teachers: The challenges of lifelong learning. Taylor \& Francis. 2002.

${ }^{27}$ Bailey, M. (2011). Policy, professionalism, professionality and the development of HR practitioners in the UK. Journal of European Industrial Training, 35(5), 487-501. https://doi.org/10.1108/03090591111138035 
activities according to their respective regions. Functional education and training programs are teacher activities in participating in training or education with the aim of achieving professional competency standards in improving the professionalism of teachers to have competencies above the average teacher professional competency standards. Therefore, in 2018 the Directorate General of GTK developed a Continuing Professional Development Program (CPD) through a Teacher Education and Training activity to improve teacher competence.

\section{III.RESEARCH METHODS}

This study is quantitative research. Ex post facto research design is the type of research that was used. This research is a field study that looks at a specific demographic or sample of people. The data analysis is a quantitative descriptive statistical analysis used to evaluate a hypothesis, namely, whether there is an effect of implementing non-formal supervision on teacher performance in Continuous Professional Development (CPD) at SMPN Makassar.

The approach in this research consists of two approaches, namely, a scientific approach and a method of collecting data using questionnaires and documentation. At the same time, the data processing and analysis technique use descriptive statistical analysis and inferential statistical analysis.

\section{IV.FINDINGS AND DISCUSSIONS}

\section{A. Description of Research Results on Implementation of Non-Formal Supervision at SMPN Makassar City}

Tabel I. Category of Non-Formal Supervision Implementation Questionnaire Results at State Junior High Schools of Makassar

\begin{tabular}{ccccc}
\hline No & Interval & Qualification & Prequency (f) & Percent (\%) \\
\hline 1 & 100 & Very High & 15 & 50 \\
2 & $98-99$ & High & 6 & 20 \\
3 & $96-97$ & Medium & 2 & 6,66 \\
4 & 95 & Low & 7 & 23,33 \\
\hline & & $\mathbf{3 0}$ & $\mathbf{1 0 0} \%$ \\
\hline
\end{tabular}

\section{HASIL ANGKET PELAKSANAAN SUPERVISI NON-FORMAL DI SMPN KOTA MAKASSAR (X)}

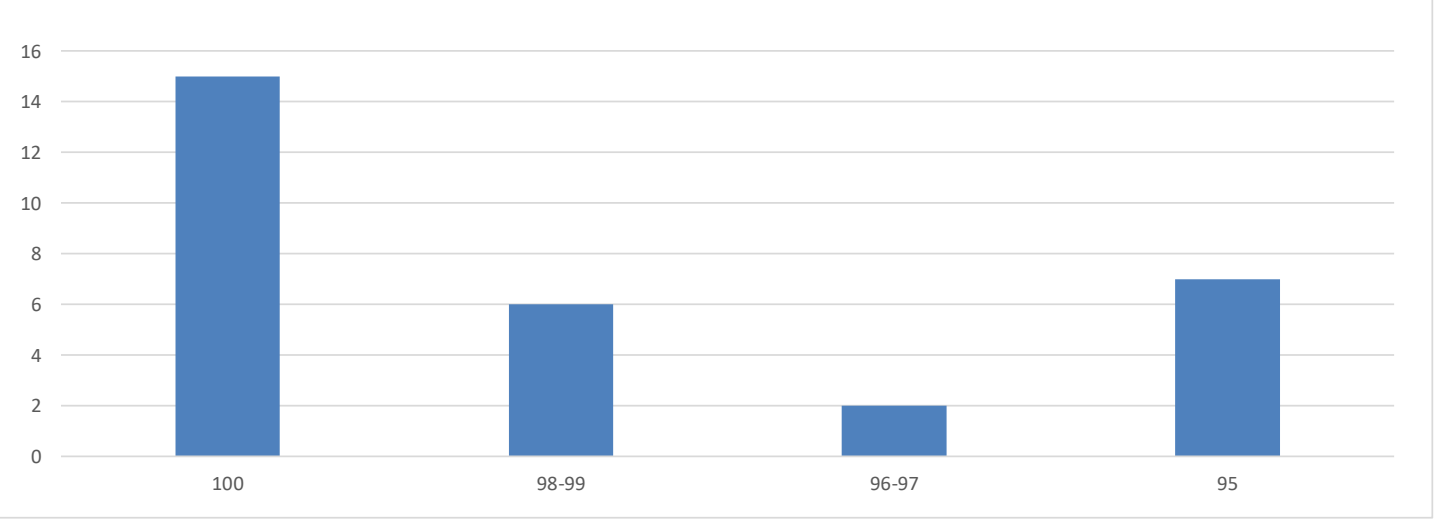


From the data above, it can be seen that the average value of non-formal supervision at SMPN Makassar is at an average of 100 as many as 15 people with $50 \%$ of the number of teachers from both schools. This means that the average non-formal supervision is in Very High qualification, meaning that non-formal supervision is carried out very well.

B. Description of Research Results on Teacher Performance in Sustainable Professional Development (PKB) at SMPN Makassar City

Tabel II. Qualification of Teacher Performance Questionnaire Results in Continuing Professional Development (CPD) at State Junior High Schools of Makassar

\begin{tabular}{ccccc}
\hline No & Interval & Qualification & Frequency (f) & Percent (\%) \\
\hline 1 & $40-41$ & Very High & 11 & 36,66 \\
2 & $38-39$ & High & 5 & 16,66 \\
3 & $36-37$ & Medium & 7 & 23,33 \\
4 & $34-35$ & Low & 7 & 23,33 \\
\hline & & $\mathbf{3 0}$ & $\mathbf{1 0 0 \%}$ \\
\hline
\end{tabular}

\section{HASIL ANGKET PELAKSANAAN KINERJA GURU DALAM \\ PENGEMBANGAN KEPROFESIONALAN BERKELANJUTAN (PKB) DI SMPN KOTA MAKASSAR}

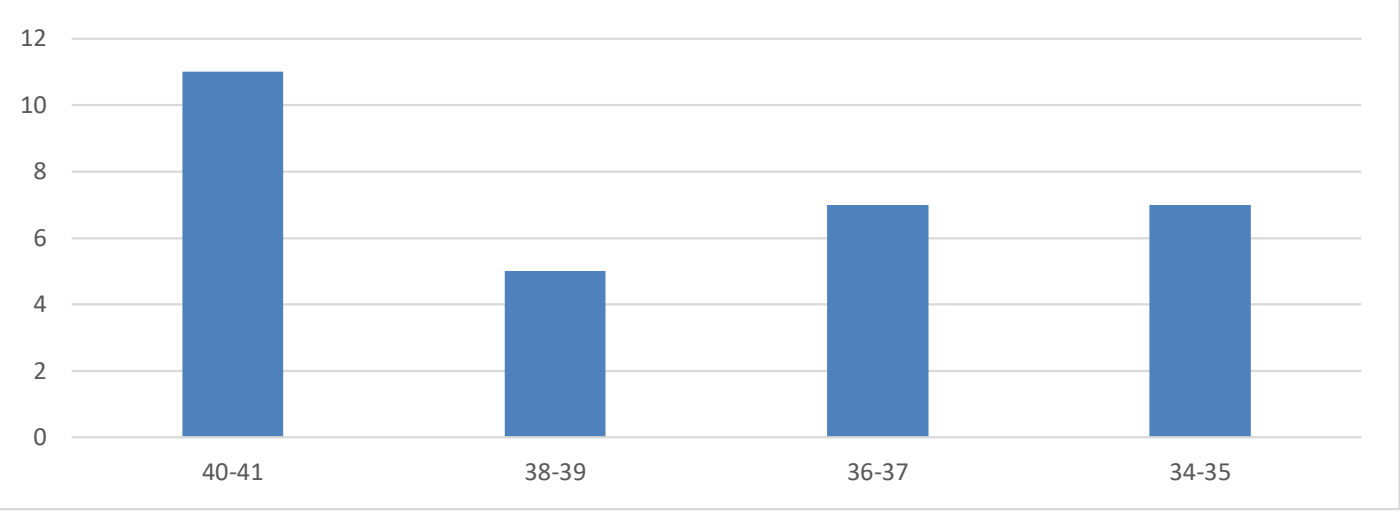

From the table data above, it can be seen that the average value of the results of the teacher performance questionnaire in Continuing Professional Development (CPD) at SMPN Makassar City is on average 40-41 as many as 11 people or about $36.66 \%$ of SMPN Makassar City teachers. This means that the average questionnaire results at SMPN Makassar City are in the Very High qualification, meaning that the teacher's performance in Continuous Professional Development (CBP) has been going very well.

C. The Effect of Non-Formal Supervision Implementation on Teacher Performance in Continuous Professional Development (PKB) at SMPN Makassar City

To find out how much influence it has, it can be known by using linear regression analysis, the calculation values obtained are presented in the following table: 
Tabel III. Regression Analysis Results

\begin{tabular}{ccl}
\hline Linear Value & $\begin{array}{c}\text { Parametric Statistical } \\
\text { Value }\end{array}$ & Description \\
\hline R &, $374^{\mathrm{a}}$ & Positive Pattern \\
R square &, 140 & Influence Pattern \\
F & 4,565 & \\
Sig. F & 0,042 & Significance \\
T & 2,137 & \\
\hline
\end{tabular}

Based on the calculations above, it is known that the correlation coefficient data acquisition with product moment analysis Values $\mathrm{R}=0.374$ and $\mathrm{R}$ square $=0.140$ means that the influence of non-formal supervision $(\mathrm{X})$ and teacher performance in Continuous Professional Development (PKB) (Y) there is a positive relationship and based on the guideline the value of the correlation coefficient and the strength of the relationship is low or not strong. The direction of the relationship between variables is known to be positive, which means that non-formal supervision (X) and teacher performance in Continuing Professional Development (CPD) (Y) also increase but the level of influence between variables is low and not strong.

Based on the value of $\mathrm{R}$ square $=0.140$, the index of the contribution of the nonformal supervision of the principal $\left(\mathrm{X}_{1}\right)$ on teacher performance $(\mathrm{Y})$ is 14.0 and the remaining $86.0 \%$ is influenced by other factors. So that the data has a positive pattern meaning that there is a relationship between the variables $(\mathrm{X})$ and $(\mathrm{Y})$ in the same direction.

Based on the previous ANOVA table, the test rules can be analyzed based on the comparison between $F_{\text {count }}$ and $F_{\text {table. }}$ The $F_{\text {count }}$ value from the ANOVA table is $=4.565$ while the $F_{\text {table }}$ value from the $F_{\text {table }}=3.32$ with a significant level value $=0.05$. So that the decision data from the simple linear regression model can be used to predict the effect of non-formal supervision (X) and teacher performance in Continuous Professional Development (CPD) (Y) at SMPN Makassar.

Based on the t-test to make a hypothesis in the form of a sentence about the presence or absence of the influence of non-formal supervision (X) and teacher performance in Continuous Professional Development (CPD) (Y) at SMPN Makassar. Testing Rules If , $t_{\text {table }}<t_{\text {count }}<t_{\text {table, }}$, then $\mathrm{H}_{\mathrm{o}}$ is accepted. If, $\mathrm{t}_{\text {count }}>\mathrm{t}_{\text {table, }}$, then Ho is rejected. Based on the coefficient table $(\alpha)$ obtained the value of tcount $=2.137$. The value of $t_{\text {table }}$ is 2.048 so that comparing $t_{\text {table }}$ and $t_{\text {count }}$ turns out to be $t_{\text {count }}=2.137>$ ttable $=$ 2.048, then $\mathrm{Ho}$ is rejected and $\mathrm{H}_{1}$ is accepted so that it is known that there is a significant influence on non-formal supervision (X) and teacher performance in Continuing Professional Development (CPD) (Y) at SMPN Makassar. Testing the significance of determining the test criteria obtained coefficients $(\alpha)$ obtained the value of sig $=0.00$ the $\alpha$ value, because the test is two-sided, the $\alpha$ value is divided by 2 , so that the $\alpha$ value $=$ $0.05 / 2=0.025$. So it is known that there is a significant effect of non-formal supervision (X) and teacher performance in Continuous Professional Development (PKB) (Y) at SMPN Makassar City. 


\section{CLOSING}

Based on the results of data analysis and discussion of research results, it can be concluded as follows.

a. Non-formal supervision at SMPN Makassar City is in the Very High category with a percentage of 50\%. This illustrates that principals are always involved in non-formal supervision activities such as brokering, participatory leadership, mediation, and relationship placement.

b. Teacher performance in Continuing Professional Development (CPD) is in the Very High category with a percentage of $36.66 \%$. This illustrates that teacher performance assessment in Continuing Professional Development (CPD) at SMPN Makassar City is very good.

c. Based on the coefficient table $(\alpha)$ obtained the value of $t_{\text {count }}=2.137$. The value of ttable can be searched for 2.048 so that comparing ttable and tcount turns out to be $\mathrm{t}_{\text {count }}=2.137>$ ttable $=2.048$, then $\mathrm{H}_{\mathrm{o}}$ is rejected, and $\mathrm{H}_{1}$ is accepted, so it is known that there is a significant effect of non-formal supervision (X) and teacher performance in Continuing Professional Development (CPD) (Y) at State Junior High Schools of Makassar.

\section{REFERENCES}

Arikunto, Suharsimi. Dasar-Dasar Supervisi. Jakarta, Rineka Cipta. 2004.

Bailey, M. Policy, Professionalism, Professionality And The Development of HR Practitioners in the UK. Journal of European Industrial Training, 35(5), 487-501. https:// doi. org/10. 1108/03090591111138035. 2011.

Collin, K., Van der Heijden, B., \& Lewis, P. Continuing professional development. International Journal of Training and Development, 16(3), 155-163. https: //doi. org/10 .1111/j.1468-2419.2012.00410. 2012.

Day, C. Developing Teachers: The challenges of Lifelong Learning. Taylor \& Francis. 2002.

Depdiknas. Undang-Undang Republik Indonesia Nomor 14 Tahun 2005 Tentang Guru dan Dosen . Jakarta:Balai Pustaka. 2008.

Direktorat Jendral Guru dan Tenaga Kependidikan. Melalui Pendidikan dan Pelatihan Guru. K. P. N. Jakarta. 2018.

Fattah, Nanang. Landasan Manajemen Pendidikan , Cet. V., Bandung: Remaja Rosdakarya. 2000.

Harris Abd. Kepemimpinan Pendidikan . Buku Perkuliahan Manajemen Pendidikan Islam. Universitas Islam Negeri Sunan Ampel (UINSA). 2013.

Kemendiknas. Pembinaan dan Pengembangan Profesi Guru Buku 1: Pedoman 
Pengelolaan Pengembangan Keprofesian Bekelanjutan (PKB). (Direktorat Jenderal Peningkatan Mutu Dan Tenaga Kependidikan. 2011.

Lee, H., \& Billington, C. The Evolution of Supply Chain Management Models and Practice dalam Hewlett-Packard. Interfaces, 25(5). 1995.

Mann, D. The Missing Link: Lean Leadership. Frontiers in Health Services Management 26(1). 2012.

Ondi Saondi \& Ari Suherman. Etika Profesi Keguruan. Cet. I; Bandung: Refika Aditama. 2011.

Packard, D. The HP Way: How Bill Hewlett and I Built our Company. New York: Harper Business. 1995.

Harris Abd. Kepemimpinan Pendidikan. Buku Perkuliahan Manajemen Pendidikan Islam. Universitas Islam Negeri Sunan Ampel (UINSA). 2013.

Piet, A. Sahertian. Konsep-Dasar dan Teknik Supervisi Pendidikan dalam Rangka Profesionalisme Guru. Surabaya: Usaha Nasional. 2000.

Piet A. Sahertian. Konsep Dasar dan Teknik Supervisi Pendidikan dalam Rangka Pengembangan Sumber Daya Manusia. Jakarta: PT Rineka Cipta (Edisi Revisi). 2018.

Rogers, B. Managing Teacher Stress. Financial Times Prentice Hall, London. 1995.

Rusman. Model-Model Pembelajaran: Mengembangkan Profesionalisme Guru. Jakarta: Raja Grafindo Persada. 2014.

Satori, Dj. Supervisi Akademik dan Penjaminan Mutu dalam Pendidikan Persekolahan. Koleksi Materi Perkuliahan Supervisi Pendidikan. Bandung. 2016.

Serrat, Olivier. A Primer on Talent Management. Washington, DC: Asian Development Bank. 2010.

Sudarwan Danim. Inovasi Pendidikan: Dalam Upaya Peningkatan. Jakarta: Bumi Aksara. 2002.

Usman, Basyaruddin Muh. Guru Profesional dan Implimentasi Kurikulum .Cet.1. Jakarta: Ciputat. 2006.

Usman, Uzer. Menjadi Guru Profesional. Bandung: PT. Remaja Rosdakarya. 2002. 